\title{
Calycosin Suppresses Epithelial Derived Initiative Key Factors and Maintains Epithelial Barrier in Allergic Inflammation via TLR4 Mediated NF-kB Pathway
}

\author{
Yu Tao a,b,c Yan Wang ${ }^{\mathrm{a}}$ Xiaoyu Wang ${ }^{\mathrm{a}}$ Can Wang ${ }^{\mathrm{a}}$ Kaifang Bao ${ }^{\mathrm{a}}$ Lv Jia,b $^{\mathrm{a}}$ \\ Guorong Jiang ${ }^{b}$ Min Hong ${ }^{a}$
}

\begin{abstract}
ajiangsu Key Laboratory for Pharmacology and Safety Evaluation of Chinese Materia Medica, School of Pharmacy, Nanjing University of Chinese Medicine, Nanjing, 'bSuzhou Traditional Chinese Medical Research Institute, The Affiliated Suzhou Hospital of TCM of Nanjing University of Chinese Medicine, Suzhou, 'Department of Pharmacology of Chinese Materia Medica, China Pharmaceutical University, Nanjing, China
\end{abstract}

\section{Key Words}

Calycosin • Atopic dermatitis • TSLP • IL-33 • Tight Junctions • Barrier function

\begin{abstract}
Background/Aims: Calycosin is a bioactive component of Astragali Radix, a Chinese herb for treating allergy. We have previously demonstrated that calycosin effectively inhibited allergic inflammation efficiently. The aim of this study was to explore the mechanism of calycosin on epithelial cells in allergic inflammation. Methods: An initial stage of atopic dermatitis (AD) model in which mice were just sensitized with FITC, was established in vivo and immortalized human keratinocytes (HaCaT cells) were utilized in vitro. Initiative key cytokines, TSLP and IL-33, were measured by ELISA, qPCR, immunofluorescence and Western blot. The junctions in epithelial cells were observed by electron microscopy and tight junctions (TJs) (Occludin and ZO-1) were assessed by Western blot and immunofluorescence. TLR4, MyD88, TAK1, TIRAP and NF-KB were measured by qPCR or Western blot. Results: The results showed that TSLP and IL-33 were inhibited significantly by calycosin in the initial stage of AD model. Simultaneously, calycosin attenuated the separated gap among the epithelial cells and increased the expression of TJs. TSLP/IL-33 and TJs were similarly affected in LPS-stimulated $\mathrm{HaCaT}$ cells in vitro. Meanwhile, calycosin not only inhibited the expressions of TLR4, MyD88, TAK1 and TIRAP, but also reduced NF-KB activation in vitro and in vivo. An NF-KB inhibitor enhanced the expressions of TJs and reduced that of TSLP/IL-33 in LPS-stimulated HaCaT cells. Conclusion: These results indicated that calycosin reduced the secretion of TSLP/IL-33 and attenuated the disruption of epithelial TJs by inhibiting TLR4 mediated NF-KB signaling
\end{abstract}

Min Hong
and Guorong Jiang

KARGER
Nanjing University of Chinese Medicine, 138 Xianlin Road, Nanjing, (China)

Suzhou Traditional Chinese Medical Research Institute, Suzhou, (China)

Tel. +862585811248. E-Mail: hongmin72@126.com, guorongjiang@hotmail.com 


\section{Cellular Physiology Cell Physiol Biochem 2017;44:1106-1119 \begin{tabular}{ll|l} 
and Biochemistry & $\begin{array}{l}\text { DOI: 10.1159/000485416 } \\
\text { Published online: November 27, } 2017\end{array}$ & $\begin{array}{l}\text { ( ) 2017 The Author(s). Published by S. Karger AG, Basel } \\
\text { www.karger.com/cpb }\end{array}$ \\
\hline
\end{tabular} \\ Tao et al.: Calycosin Suppresses Allergic Inflammation}

pathway. These findings help to understand the beneficial effects of calycosin on $A D$, and to develop effective preventive or therapeutic strategies to combat this disease and other epithelial barrier deletion-mediated allergic diseases.

\section{Introduction}

Atopic dermatitis (AD) is one of the most common human skin diseases and now a major health problem worldwide. The development of $\mathrm{AD}$ is mainly attributed to geneticpolymorphisms, skin barrier dysfunction, environmental exposures, and host immune dysregulation [1]. Currently, established therapeutic therapies for AD is mainly by topical glucocorticosteroids, however, bad client compliance and low prescription rates greatly restricted the use of drugs [2]. Therefore, potent natural-derived compounds have been searched to treat $\mathrm{AD}$ in recent years.

Calycosin, an isoflavonoid, is a major active component in Astragali Radix that has been widely used to treat allergic inflammation in clinical practice. We have previously found FITC-induced allergic inflammation was attenuated by only administering calycosin in the initial stage of sensitization. Calycosin was able to inhibit the degree of ear swelling and ear histopathological level in mice [3]. However, the underlying mechanisms of calycosin have not been illustrated.

Investigations suggest that epithelium play active roles in AD. Firstly, the epithelium serves as a barrier by means of tight junctions (TJs) formation, which seals off the paracellular space, and possesses a gate function that selectively regulates the passage of ions and molecules [4,5]. Among different TJ proteins, occludin and ZO-1 are predominantly involved in regulating the epithelial barrier [6-8]. Occludin, the first discovered integral membrane protein of TJs, is most ubiquitously expressed at the apicalmost basolateral membranes and is the most reliable marker for TJs [9]. ZO-1 is considered as a scaffolding protein, linking T] transmembrane proteins to cytoskeletal filaments. Studies have shown that ZO-1 is required for occludin to be localized at TJs [10]. Disrupting either the expression or the distribution of ZO-1 leads to disruption of TJ assembly [11]. Moreover, disturbed skin barrier function such as that caused by TJs significantly increases the risks of $\mathrm{AD}$ and atopic diathesis [12,13]. Kim et al. reported that the expressions of occludin and ZO-1 were decreased in the atopic group by immunohistochemistry in experimental AD model in dogs [14].

Meanwhile, the epithelium controls inflammatory and regenerative responses to allergens, viruses, and environmental pollutants that contribute to the pathogenesis of AD. In response to allergen triggers, the epithelium secretes various cytokines that are strongly implicated in Th2-polarized inflammation [15]. The release of IL-33/TSLP by the epithelium is an important proximal event in the induction and maintenance of Th2 inflammation $[16,17]$, and they are known as initiative key factors of allergic inflammation. TSLP expression level increases in AD patients, which can be used as a biomarker of AD severity and particularly the epidermal barrier status [18]. It may also be a master switch for allergic inflammation at the EC-DC interface [19]. IL-33 is a newly recognized member of the IL-1 cytokine family that has recently been attributed to the epithelial "alarmin" defense system [20]. Furthermore, IL-33 can increase TSLP expression following an Egr-1-dependent mechanism through ERK1/2, JNK and p38 activations in keratinocytes [21]. Therefore, it is reasonable to explore the mechanism of drug action from the perspective of epithelial cell function.

Various Toll-like receptors (TLRs) are important mediators of innate immune that recognizes pathogen-associated microbial patterns from microbial and viral products and activates distinct signaling pathways [22]. In the whole process of inflammation, NF- $\kappa \mathrm{B}$ is one of the most important transcription factors known to regulate the expressions of genes involved in allergic inflammation [23-25]. Recent studies reported that, TLR4-mediated $N F-\kappa B$ signaling plays an important regulatory role in epithelial homeostasis [26-28]. The activation of TLR4 results in that of NF- $\kappa B$ through multiple downstream intracellular signals, and then the synthesis of pro-allergic cytokines, including TSLP [29] and IL-33 [30], 


\section{Cellular Physiology Cell Physiol Biochem 2017;44:1106-1119 \begin{tabular}{ll|l} 
and Biochemistry $10.1159 / 000485416$ & $\begin{array}{l}\text { C 2017 The Author(s). Published by S. Karger AG, Basel } \\
\text { Published online: November 27, } 2017\end{array}$ \\
\cline { 2 - 2 }
\end{tabular} \\ Tao et al.: Calycosin Suppresses Allergic Inflammation}

is stimulated to induce inflammatory cell recruitment and activation. Accordingly, it may stimulate the acute phase inflammatory reaction upon AD. However, whether TLRs signaling pathways are involved in the disruption of TJ proteins is still unknown.

Our previous studies have demonstrated that administering of calycosin at the early stage inhibited later allergic inflammation, suggesting that it was involved in the early pathological process. As stated above, epithelial cells play a key role in early stage of allergic inflammation. Thereby motivated, objective of this study was to explore the mechanism of calycosin attenuating $\mathrm{AD}$ from the perspective of epithelial cell function.

\section{Materials and Methods}

\section{Chemicals}

Calycosin was purchased from Tianjin Marker Bio-Tech Co. Ltd (Tianjin, China, Purity: $\geq 98.75 \%$ ). Dexamethasone was a product from TianYao Pharmaceutical Co., Ltd (Hubei, China).

Animals and cells

BALB/c mice were purchased from Shanghai Slac Laboratory Animal Company. All animals, 6-10 weeks of age, were maintained at Nanjing University of Chinese Medicine under specific pathogen-free conditions at $18^{\circ} \mathrm{C}-25^{\circ} \mathrm{C}$ and $50 \%-60 \%$ humidity. All procedures involving animals were approved by the Animal Care and Use Committee of Nanjing University of Chinese Medicine and strictly performed according to the Guide for the Care and Use of Laboratory Animals. HaCaT cells (Immortalized human keratinocytes) were purchased from the Cell Bank of the Chinese Academy of Medical Sciences (Beijing, China) and cultured in MEM medium (Hyclone, Thermo scientific, USA) supplemented with 10\% fetal bovine serum (Capricron scientific, Germany) at $37^{\circ} \mathrm{C}$ and $5 \% \mathrm{CO}_{2}$.

\section{Initial stage of $A D$ model in vivo}

Initial stage of $\mathrm{AD}$ model was established as described previously [3]. Briefly, BALB/c mice were treated with $0.6 \%$ fluorescein isothiocyanate (FITC; Sigma, USA) in $20 \mu \mathrm{L}$ acetone and dibutylphthalate (1:1, vehicle) on both ears on day 1 and 2, and sacrificed on day 3. $20 \mu \mathrm{L}$ acetone and dibutylphthalate was applied as vehicle control (control group). FITC treated mice were administered once daily with calycosin (0.4, 2 or $10 \mathrm{mg} / \mathrm{kg}$, intragastrically) or normal saline as negative control (model group) 2 days before treatment with FITC until day 3 of the model. Both ears were removed and ground into homogenates with ice-phosphate-buffered saline (PBS), and the homogenates were centrifuged at $4000 \mathrm{~g}$ at $4^{\circ} \mathrm{C}$ for $15 \mathrm{~min}$.

\section{Cell culture and treatment in vitro}

HaCaT cells were seeded into 6 -well plates at a density of $1 \times 10^{6}$ cells $/ \mathrm{mL}$ and incubated at $37^{\circ} \mathrm{C}$ under $5 \% \mathrm{CO}_{2}$. Cells were pretreated with calycosin (in medium with $0.05 \%$ DMSO) or medium with $0.05 \%$ DMSO as vehicle (control) for $6 \mathrm{~h}$ and stimulated with LPS $(10 \mu \mathrm{g} / \mathrm{mL}$; Sigma) simultaneously for $24 \mathrm{~h}$. For immunofluorescence assay, cells were seeded on the coverslips in 12-well plates and treated under the same condition as above.

\section{ELISA assay for TSLP and IL-33}

The concentrations of TSLP and IL-33 in cell culture supernatant were quantified by Human TSLP ELISA kit (both isoforms: IfTSLP and sfTSLP, eBioscience, San Diego, CA, USA) and Human IL-33 ELISA kit (Becton, Dickinson and Company, USA).The concentrations of TSLP (both isoforms: IfTSLP and sfTSLP) and IL-33 in ear homogenate of mice were measured by mouse TSLP and IL-33 ELISA kits (eBioscience, San Diego, CA, USA). Total protein levels in the homogenates were examined by Pierce ${ }^{\mathrm{TM}}$ BCA Protein Assay Kit (Thermo scientific, USA). TSLP and IL-33 protein levels were assessed with the formula: concentration of TSLP and IL-33 in the homogenate/total protein (pg/mg).

\section{RNA isolation and Quantitative real-time PCR ( $P$ PCR) assay}

Ear tissues of each group were homogenized in $1 \mathrm{ml}$ of TRIzol (Life Technologies, USA) using a glass homogenizer. The total RNA was isolated according to the manufacturer's protocol. The SYBR green PCR 

Cellular Physiology Cell Physiol Biochem 2017;44:1106-1119 \begin{tabular}{ll|l} 
and Biochemist 10.1159/000485416 & $\begin{array}{l}\text { ( ) 2017 The Author(s). Published by S. Karger AG, Basel } \\
\text { www.karger.com/cpb }\end{array}$ \\
\hline
\end{tabular}
Tao et al.: Calycosin Suppresses Allergic Inflammation

Master Mix (Thermo scientific, USA) was used for real-time PCR analysis. All reactions were run on an ABI 7500 Fast Real-Time PCR System (Applied Biosystems, USA). Oligonucleotide sequences of PCR primers (Shenggon Biotech, Shanghai, China) are listed (Table 1). The cycle time value of the interested gene was normalized with GAPDH of the same sample; fold induction of gene expression was calculated using the $\Delta \Delta \mathrm{Ct}$ method and was expressed as relative mRNA expression to GAPDH.
Table 1. Oligonucleotide sequences of quantitative real-time PCR.

\begin{tabular}{|c|c|c|}
\hline Gene & Primer & $\begin{array}{l}\text { Sequences } \\
\end{array}$ \\
\hline \multirow{2}{*}{ TSLP } & Forward & $5^{\prime}$ - TACTATACTCTCAATCCTATCCCTG-3 \\
\hline & Reverse & 5'- АCTTCTTGTGCCATTTCCTG -3' \\
\hline \multirow{2}{*}{ IL-33 } & Forward & 5'- TCCAАСТCСAAGATTTCCCCG-3' \\
\hline & Reverse & 5'- CATGCAGTAGACATGGCAGAA-3' \\
\hline \multirow[t]{2}{*}{ TLR4 } & Forward & 5'-TGGTTTACACGTCCATCGGT-3' \\
\hline & Reverse & 5'- ATCAATGGTCACATCACATAGTCC-3' \\
\hline \multirow[t]{2}{*}{ MyD88 } & Forward & 5'- TGGCCTTGTTAGACCGTGA-3' \\
\hline & Reverse & 5'- AAGTATTTCTGGCAGTCCTCCTC-3' \\
\hline \multirow[t]{2}{*}{$N F-\kappa B$} & Forward & 5'- TCTCTATGACCTGGACGACTCTT-3' \\
\hline & Reverse & 5'- GCTCATACGGTTTCCCATTTAGT-3' \\
\hline \multirow{2}{*}{ GAPDH } & Forward & 5'- GGTTGTCTCCTGCGACTTCA -3' \\
\hline & Reverse & 5'- TGGTCCAGGGTTTCTTACTCC-3' \\
\hline
\end{tabular}

\section{Western blot analysis of protein expression}

Ear tissues of mice were ground into homogenates with $20 \mu \mathrm{L} / \mathrm{mg}$ protein lysis solution (RIPA, phenylmethylsulfonyl fluoride and phosphatase inhibitor; 100:1:1). As for in vitro experiment, HaCaT cells were scraped from 6-well plates containing $100 \mu \mathrm{L}$ of RIPA: phenylmethylsulfonyl fluoride (100:1). The samples (either from ear tissues or cells) were collected in to microcentrifuge tubes, and lysed for $20 \mathrm{~min}$. Then the homogenates were centrifuged at $13200 \mathrm{~g}$ at $4^{\circ} \mathrm{C}$ for $10 \mathrm{~min}$. The protein concentrations of the tissue or cell samples were determined using a BCA protein assay kit (Thermo scientific, USA). Total protein extracts were resolved by SDS-AGE and transferred onto polyvinylidenedifluoride membranes (Millipore, USA). After blocking with skim milk, the membranes were washed with Tris-buffered saline containing 0.1\% Tween-20 (TBST) five times for $5 \mathrm{~min}$ at room temperature and then incubated with antibodies against TSLP, IL-33, TLR4 (1:1000, Santa Cruz Biotechnology, USA), Occludin, NF-кB p65 (1:1000 dilution; Abcam, England), ZO-1 (1:1000, proteintech, USA), MyD88 (1:1000, Cell Signaling Technology, USA), TAK1

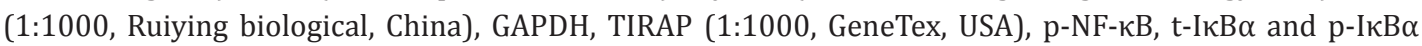
(1:1000, Cell Signaling Technology, USA) at $4^{\circ} \mathrm{C}$ overnight. After washing, membranes were incubated at room temperature with secondary peroxidase-linked goat anti-rabbit IgG or goat anti-mouse IgG (1:1000 dilution; Santa Cruz Biotechnology, USA) for $2 \mathrm{~h}$. After washing, protein bands were detected by enhanced chemiluminescence (ECL kit; Millipore, USA) and the protein expressions were quantified by ChemiScope analysis.

\section{Immunofluorescence staining analysis}

TSLP, IL-33 and TJs proteins expressed in HaCaT cell were evaluated by immunofluorescence assay. The cells on the coverslips were fixed in methanol for $20 \mathrm{~min}$ at $-20^{\circ} \mathrm{C}$ and washed with PBS. For cytokines detection, the cells were permeabilized with Triton X-100 (Genview, Scientific Inc, USA) for 10min, while this procedure was not needed for TJs proteins. The endogenous peroxidase was blocked by incubating in $3 \% \mathrm{H}_{2} \mathrm{O}_{2}$ for $20 \mathrm{~min}$, and non-specific binding sites were blocked with $10 \%$ bovine serum albumin (BSA) for $1 \mathrm{~h}$ at $37^{\circ} \mathrm{C}$. The cells were probed with rabbit monoclonal antibodies against TSLP and IL-33 (1:200 dilution; Santa Cruz Biotechnology, USA) or ZO-1 (1:200 dilution; proteintech, USA) and Occludin (1:200 dilution; Abcam, England) at $4{ }^{\circ} \mathrm{C}$ overnight. After repeated washes with PBS, the cells were incubated with goat anti-rabbit IgG conjugated to FITC (1:200; dilution; Santa Cruz Biotechnology, USA) and 4',6-diamidino2-phenylindole (DAPI, Bioword, China) at a concentration of $0.1 \mu \mathrm{g} / \mathrm{mL}$ for $10 \mathrm{~min}$. Photomicrographs were obtained using afluorescence optical microscopy (Mantra, PerkinElmer, USA).

\section{Transmission electron microscopy (TEM)}

The ear tissue specimen was first fixed with $2.5 \%$ glutaraldeyde in PBS for more than $4 \mathrm{~h}$; washed three times in PBS, then postfixed with $1 \% \mathrm{OsO}_{4}$ for $1 \mathrm{~h}$ and washed four times in PBS. The specimen was dehydrated by a graded series of ethanol (30\%, 50\%, 70\%, 80\%, 90\% and 100\%) for about 15 min at each step and transferred to absolute acetone for $20 \mathrm{~min}$. Afterwards, the specimen was placed in 1:1mixture of absolute acetone and the resin for $1 \mathrm{~h}$ at room temperature, then transferred to $1: 3$ mixture of absolute 


\section{Cellular Physiology Cell Physiol Biochem 2017;44:1106-1119

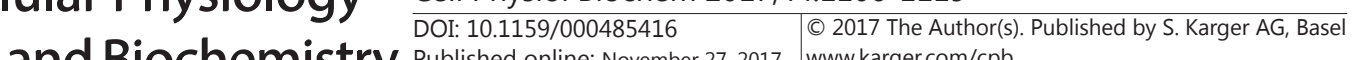 Published online: November 27, 2017 www.karger.com/cpb \\ Tao et al.: Calycosin Suppresses Allergic Inflammation}

acetone and the resin for $3 \mathrm{~h}$ and to final resin for overnight. After that, specimen was placed in capsules contained embedding medium and heated at $70^{\circ} \mathrm{C}$ for $48 \mathrm{~h}$. The $70 \mathrm{~nm}$ of specimen sections were stained by acetate and alkaline lead citrate for 15 min respectively and observed in transmission electron microscope (JEOL, Japan).

\section{Molecular Docking}

Molecular docking study was performed to investigate the binding mode between the calycosin and the human toll-like receptor 4 (TLR4) using Autodockvina 1.1.2 [31]. The three-dimensional (3D) structure of the human TLR4 (PDB ID: 3FXI). The 3D structure of the calycosin was drawn by ChemBioDraw Ultra 14.0 and ChemBio3D Ultra 14.0 softwares. The Auto Dock Tools 1.5.6 package [32] was employed to generate the docking input files. The best-scoring pose as judged by the Vina docking score was chosen and visually analyzed using PyMoL1.7.6 software.

\section{Statistical analysis}

The data were expressed as means \pm SD. Multiple groups' comparisons were analyzed by one-way analysis of variance, and Dunnett's test was used for comparison between two groups, with GraphPad Prism 5 (GraphPad Software, San Diego, CA, USA). Statistical significance was set at $P<0.05$.

\section{Results}

Calycosin inhibited expressions of initiative key factors in the initial stage of mice AD model

In the initial stage of AD model, mice were treated once daily with $0.4,2$ or $10 \mathrm{mg} / \mathrm{kg}$ calycosin intragastrically 2 days before treatment with FITC until day 3 of the model. The results showed that protein levels of TSLP and IL-33 in the model group were significantly

Fig. 1. Calycosin reduced initiative key factors expressions in the initial stage of $\mathrm{AD}$ model. (A) Flow charts of the initial stage of $\mathrm{AD}$ model in mice. The concentration of TSLP and IL-33 in ear homogenate was analyzed by ELISA kits. TSLP and IL-33 level was assessed with the formula: concentration of TSLP/ IL-33 in the homogenate/total protein (pg/mg). (B) The relative

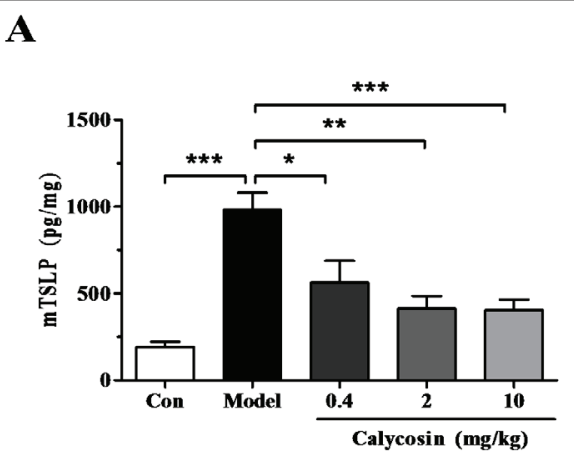

B

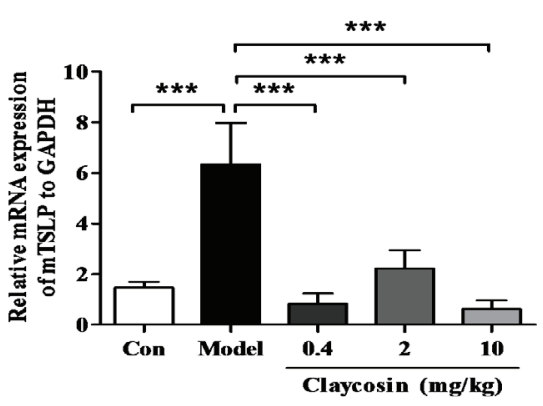

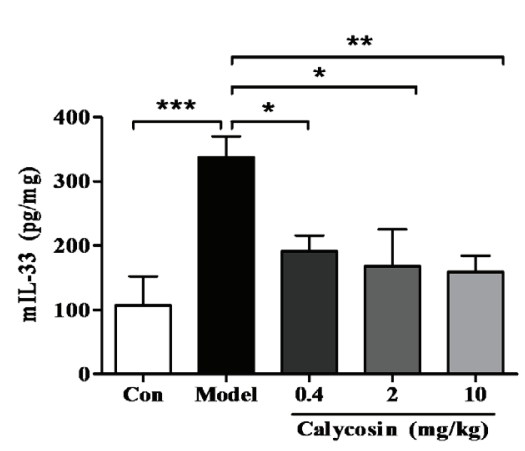

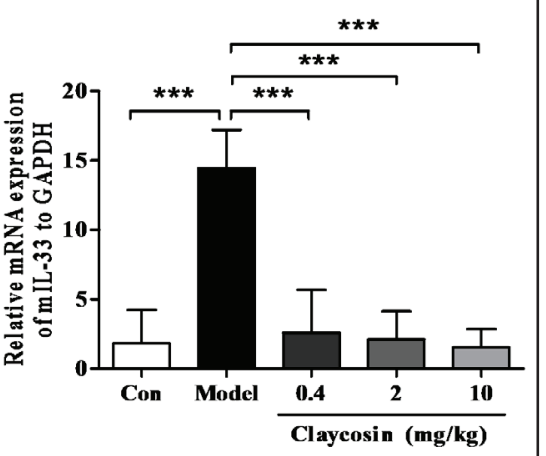
mRNA expression of TSLP and IL-33. The right ear was collected to investigate the mRNA expressions of TSLP and IL-33, analyzed with Quantitative real-time PCR. ${ }^{*} \mathrm{P}<0.05,{ }^{* *} \mathrm{P}<0.01,{ }^{* * *} \mathrm{P}<0.001$. $\mathrm{P}$-values were analyzed by one-way ANOVA. All data are representative of two to three independent experiments with $n=6$ per group and are means \pm SD. 


\section{Cellular Physiology Cell Physiol Biochem 2017;44:1106-1119 \begin{tabular}{ll|l} 
and Biochemistry & DOI:10.1159/000485416 & $\begin{array}{l}\text { @ 2017 The Author(s). Published by S. Karger AG, Basel } \\
\text { www.karger.com/cpb }\end{array}$ \\
\cline { 2 - 3 }
\end{tabular} \\ Tao et al.: Calycosin Suppresses Allergic Inflammation}

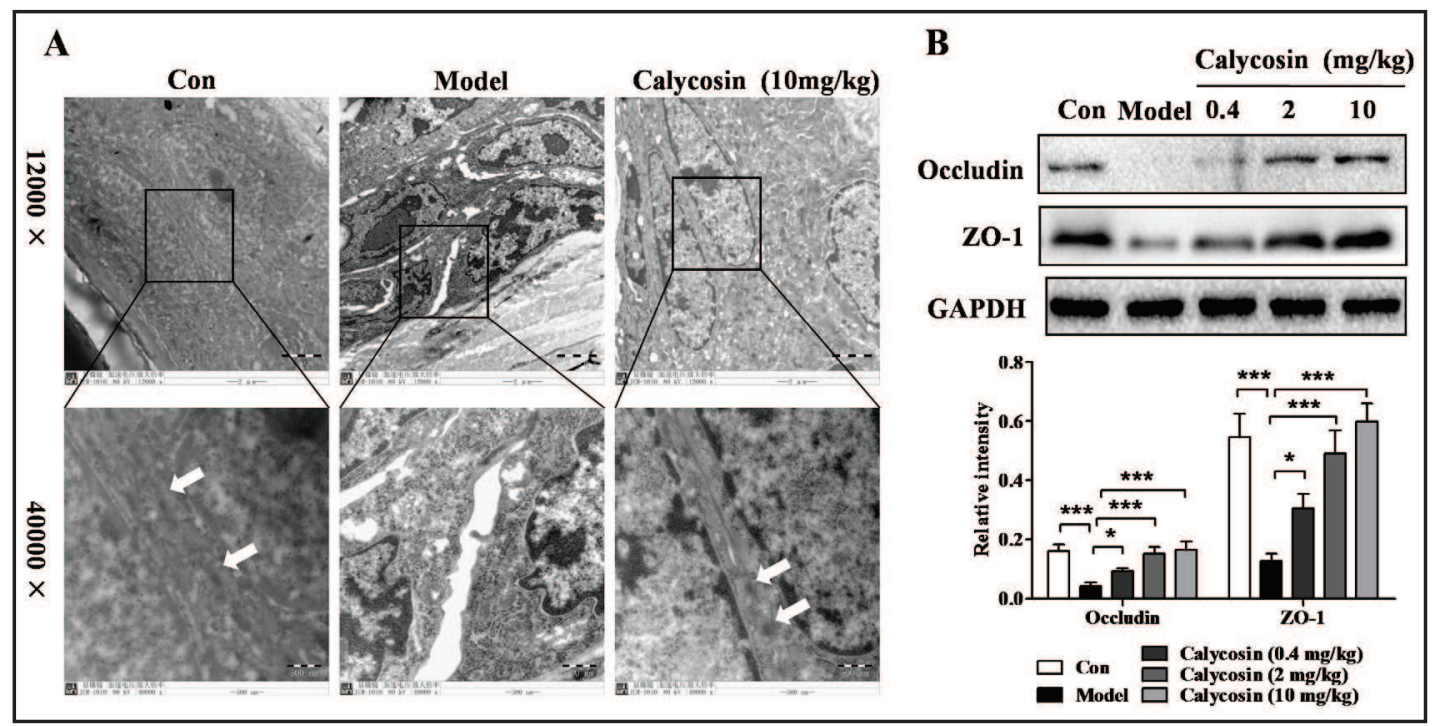

Fig. 2. Effect of calycosin on expression of TJ proteins in initial stage of AD model in mice. (A) Ultrastructure of TJs in ear tissue was observed by TEM. Arrows indicate tight junctions. Scale bars. (B) Calycosin significantly inhibited FITC-induced decreased expression of TJ proteins by western blot analysis in mice. ${ }^{*} \mathrm{P}<0.05$, ${ }^{* * *} \mathrm{P}<0.001$. NS, not significant. $\mathrm{P}$-values were analyzed by one-way ANOVA. All data are representative of two to three independent experiments with $n=3$ per group and are means \pm SD.

higher than those in the control group, but they were reduced significantly after calycosin intervention (Fig. 1A). Consistently, the mRNA levels of TSLP and IL-33 were also reduced remarkably by claycosin (Fig. 1B), indicating that calycosin inhibited the production of initiative key factors in the initial stage of allergic inflammation.

Calycosin attenuated FITC-induced dysregulation of TJs in vivo

To determine whether the physiological changes in the epithelium barrier were accompanied by altered distribution of TJs, we analyzed the epithelial connection by TEM and TJs expressions by Western blot. The normal epithelium was connected closely and structured clearly between adjacent cell membranes, forming a complete epithelial tissue structure in the ear tissue of mice. The gap between epithelial cells was significantly increased and cellcell junctions became obviously loose after FITC sensitization. However, calycosin (10 mg/ $\mathrm{kg}$ ) reversed the effects induced by FITC (Fig. 2A). Western blot results showed occluding and ZO-1 protein levels were reduced obviously in mice after FITC indution. Treatment with $0.4,2$ and $10 \mathrm{mg} / \mathrm{kg}$ calycosin elevated the expressions of TJs to various extents (Fig. 2B).

Calycosin suppressed expressions of initiative key factors in HaCaT cells in vitro

Next, we determined whether calycosin could inhibit the release of TSLP and IL-33 derived from epithelium in response to LPS stimuli in HaCaT cells. The expressions of TSLP and IL-33 were detected after exposure to LPS, while calycosin treatment significantly reduced these initiative key factors, as evidenced by immunofluorescence and Western blot (Fig. 3A and B). To further verify the effect of calycosin on the protein expressions of TSLP and IL-33, their secretion levels in cell supernatant were detected by ELISA. Consistent with the results of immunofluorescence and Western blot, the secretion levels of TSLP and IL-33 were also significantly decreased by calycosin in HaCaT cell supernatant (Fig. 3C).

Calycosin ameliorated LPS-induced dysregulation of TJs in HaCaT cells

LPS, a ligand of TLR4, has been shown to induce the redistribution of occludin and ZO-1 from intercellular junctions $[33,34]$. To confirm the in vivo findings, we further assessed the effect of calycosin on TJs in HaCaT cells. Cells were pretreated with calycosin for $6 \mathrm{~h}$, and 


\section{Cellular Physiology Cell Physiol Biochem 2017;44:1106-1119 \begin{tabular}{ll|l} 
and Biochemistry Published online: November 27, 2017 & $\begin{array}{l}\text { (c) } 2017 \text { The Author(s). Published by S. Karger AG, Basel } \\
\text { www.karger.com/cpb }\end{array}$
\end{tabular}}

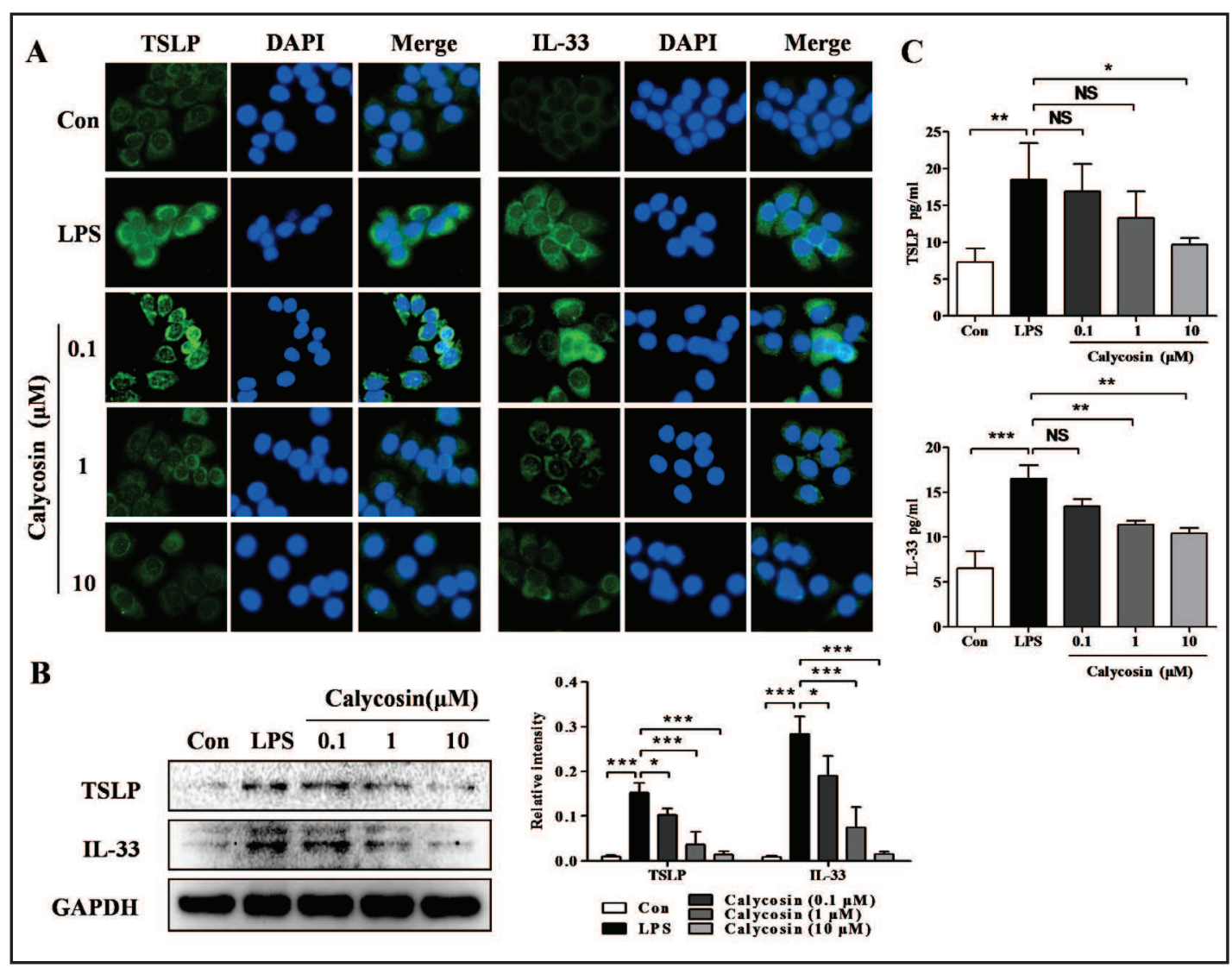

Fig. 3. Effect of calycosin on LPS-induced expressions of TSLP and IL-33 in HaCaT cells. (A) Immunofluorescent analysis of TSLP and IL-33 expression in HaCaT cells after treatment with LPS in the presence or absence of calycosin. (B) Western blot analysis for TSLP and IL-33 proteins in HaCaT cells after treatment with LPS in the presence or absence of calycosin. (C) HaCaT cell supernatants were collected $24 \mathrm{~h}$ after treatment with LPS in the presence or absence of calycosin, TSLP and IL-33 were analyzed by ELISA. ${ }^{*}<0.05,{ }^{* *} \mathrm{P}<0.01$, ${ }^{* * *} \mathrm{P}<0.001$. NS, not significant. $\mathrm{P}$-values were analyzed by one-way ANOVA. All data are representative of two to three independent experiments with $\mathrm{n}=3$ per group and are means \pm SD.

then were exposed to LPS for $24 \mathrm{~h}$. Immunofluorescence results demonstrated that occludin and ZO-1 were disrupted in HaCaT cells treated with LPS, whereas treatment with 0.1, 1 and $10 \mu \mathrm{M}$ calycosin significantly attenuated such disruption (Fig. 4A). The Western blot and immunofluorescence results were consistent, revealing the protective effect of calycosin on the TJs (Fig. 4B). The data above implied that calycosin could ameliorate AD probably via suppressing epithelium derived TSLP/IL-33 release and reducing TJs disruption.

TLR4 and its downstream molecules were regulated by calycosin in vivo

To determine whether the expressions of TLR4 and its main downstream molecules could be inhibited by calycosin in the initial stage of AD in mouse model, we tested the expression of TLR4 and its main downstream molecules in protein or mRNA expression levels. The expression of TLR4 was increased in model group compared with that in the control group. However, the expression decreased after treatment with 2 and $10 \mathrm{mg} / \mathrm{kg}$ calycosin treatment (Fig. 5A and C). The main downstream adaptor molecules of TLR4, such as MyD88, TIRAP and TAK1, are critical for it to activate downstream signaling pathways and to induce inflammatory response. The results showed that calycosin reduced the expression of MyD88, TIRAP and TAK1significantly (Fig. 5B and C). Besides, calycosin treatment significantly decreased the expression level of NF- $\kappa B$ (Fig. 5C). Taken together, these data 

Cellular Physiology Cell Physiol Biochem 2017;44:1106-1119 \begin{tabular}{ll|l} 
DOI:10.1159/000485416 & () 2017 The Author(s). Published by S. Karger AG, Basel
\end{tabular} and Biochemistry Published online: November 27, 2017 www.karger.com/cpb
Tao et al.: Calycosin Suppresses Allergic Inflammation

Fig. 4. Effects of calycosin and LPS on the junctional localization of occluding and ZO-1 as well as the expression of occludin and ZO-1 in $\mathrm{HaCaT}$ cells. (A) Immunofluorescent staining showing the effects of calycosin on the expressions of occludin and ZO-1 exposed to LPS. The phenotype of nuclei was also investigated via DAPI staining. (B) Western blot analysis for occludin and ZO-1 proteins in $\mathrm{HaCaT}$ cells after treatment with LPS in the presence or absence of calycosin. ${ }^{* *} \mathrm{P}<0.01$, $* * * \mathrm{P}<0.001$. NS, not significant. P-values

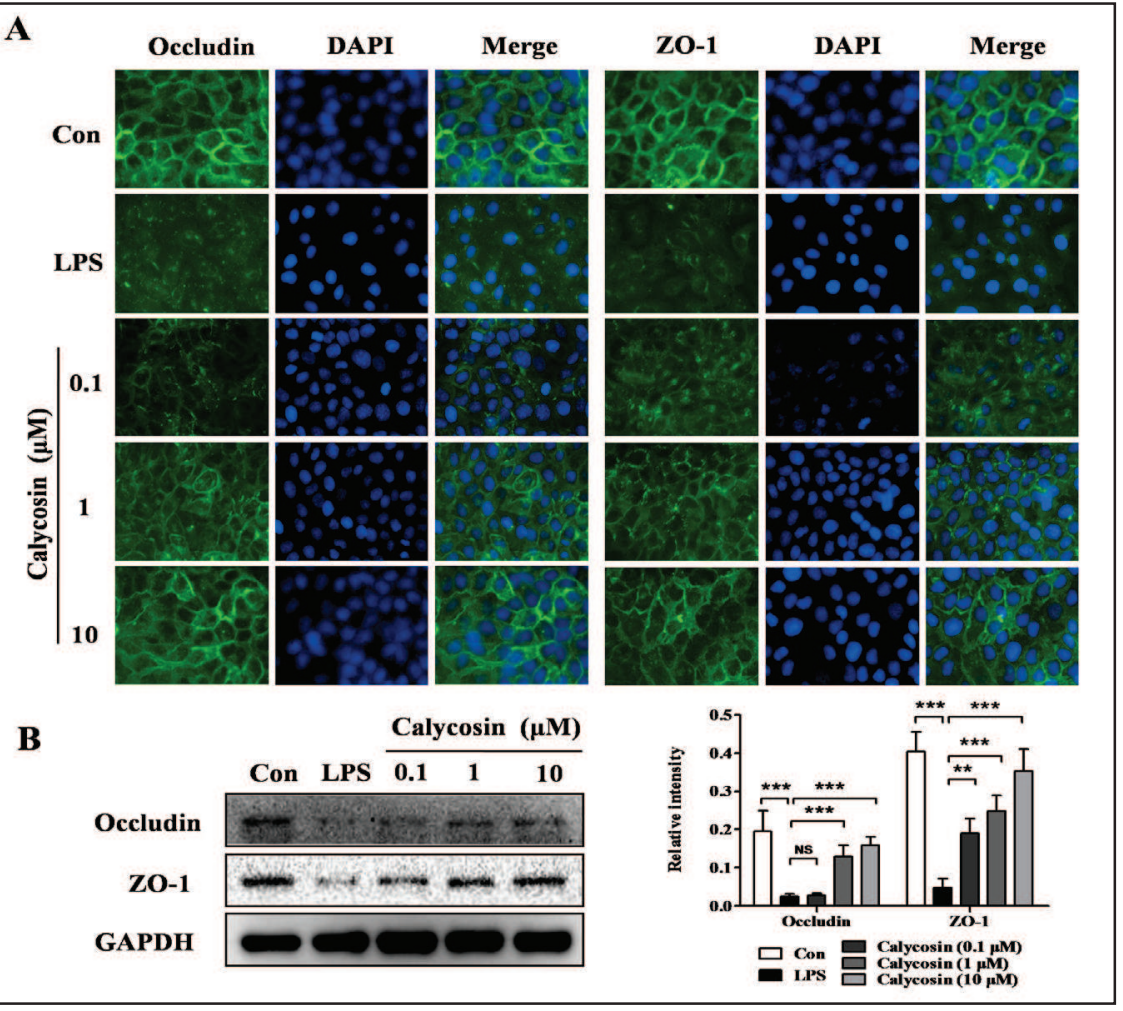
were analyzed by one-way ANOVA. All data are representative of two to three independent experiments with $n=3$ per group and are means \pm SD.

provide one possible mechanism that calycosin attenuated epithelial TJs disruption and inhibited TSLP/IL-33 release probably by blocking TLR4-mediated NF- $\kappa B$ signaling in the initial stage of AD model.

TLR4 signaling activation was inhibited by calycosin in HaCaT cells

Similar to the findings in vivo, it was demonstrated that pretreatment with calycosin reduced TLR4 expression in LPS-stimulated HaCaT (Fig. 6A). Furthermore, stimulating HaCaT cells with LPS for $24 \mathrm{~h}$ increased the protein expressions of MyD88, TAK1 and TIRAP, which were inhibited by pretreatment with 1 and $10 \mu \mathrm{M}$ (Fig. 6B). An in-depth analysis of molecular operating environment (MOE) docking module showed that calycosin extended deep into the TLR4 and interacted with hydrophobic residues at Tyr-296, Asp-294, Tyr-292, Arg-264 and Asn-339, these interactions helped calycosin and to anchor in the binding site of the TLR4 (Fig. 6C). Collectively, calycosin may inhibit activation of the allergic inflammatory cascade through TLR4 and its related signaling pathway, thereby protecting the epithelium function.

Calycosin promoted the TJs expressions and inhibited the initiative key factors mainly by inhibiting NF-kB activation

To verify the role of NF- $\kappa B$ in the release of TSLP/IL-33 and TJs disruption induced by LPS, we incubated HaCaT cells with different concentrations of NF- $\kappa B$ inhibitor PDCT and found that $20 \mu \mathrm{M}$ was the best inhibitory concentration (Fig. 7A). The cells were pretreated with $20 \mu \mathrm{M}$ PDTC for $1 \mathrm{~h}$, and then treated with LPS for $24 \mathrm{~h}$. Our date showed that PDTC reversed the decrease of occludin and ZO-1 expressions induced by LPS (Fig. 7B). Interestingly, TSLP and IL-33 expressions induced by LPS were also partially inhibited by pretreatment with PDTC as well (Fig. 7C). Hence, NF- $\mathrm{BB}$ activation, which associated with the TLR4 signaling 


\section{Cellular Physiology Cell Physiol Biochem 2017;44:1106-1119 \begin{tabular}{|l|l|l|l|l|l|l}
\hline DOI: 10.1159/000485416 & 2017 The Author(s). Published by S. Karger AG, Basel \\
\hline
\end{tabular} and Biochemistry Published online: November 27, 2017 www.karger.com/cpb

Fig. 5. Effect of calycosin on TLR4 and its downstream expressions in initial stage of AD model in mice. (A) Protein level ofTLR4 was evaluated by western blot analysis. (B) The mRNA levels of TLR4, MyD88 and $\mathrm{NF}-\kappa \mathrm{B}$ were evaluated by qPCR. (C) The protein levels of MyD88, TIRAP and TAK1 in ear tissue were analyzed by western blot analysis. ${ }^{*} \mathrm{P}<0.05,{ }^{* *} \mathrm{P}<$ $0.01,{ }^{* * *} \mathrm{P}<0.001$. NS, not significant. P -values were analyzed by one-way ANOVA. All data are representative of two to three independent experiments with $n=3-6$ per group and are means \pm SD.

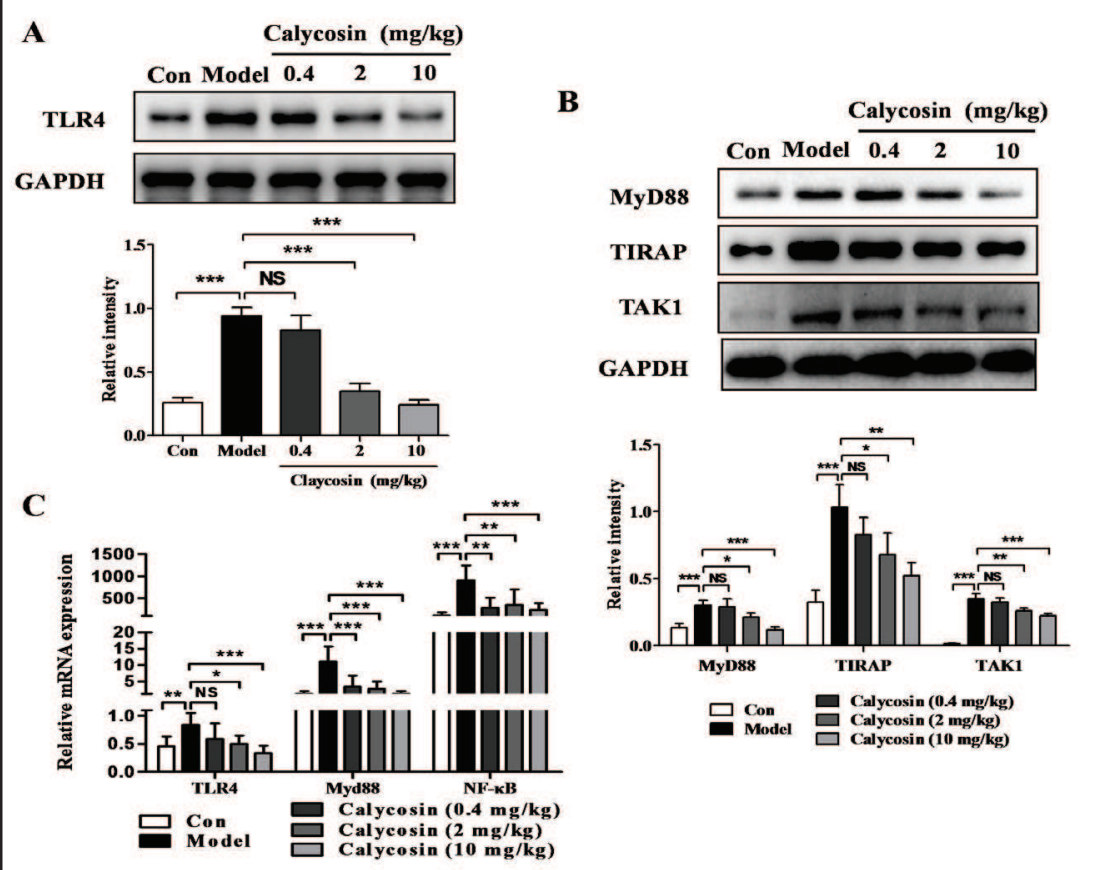

Fig. 6. Effect of calycosin on LPS-induced expression of TLR4 and its downstream expression in HaCaT cells. (A) Western blot analysis for TLR4 proteins in HaCaT cells after treatment with LPS in the presence or absence of calycosin. (B) The protein levels of MyD88, TIRAP and TAK1 in HaCaT cells were analyzed by western blot analysis. (C) The docking between calycosin and TLR4 in HaCaT cells. ${ }^{*} \mathrm{P}<0.05,{ }^{* *} \mathrm{P}<$ $0.01,{ }^{* * *} \mathrm{P}<0.001$. NS,

A
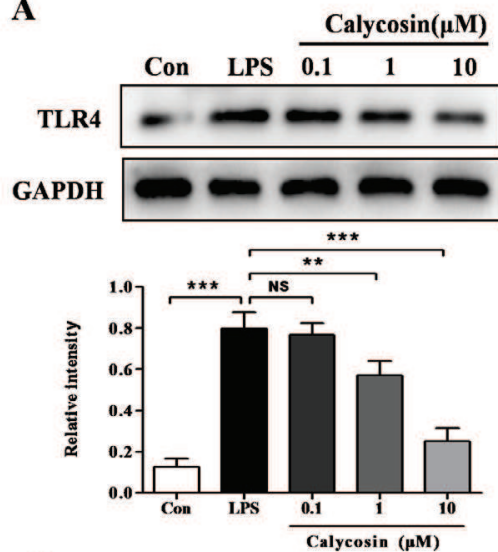

C

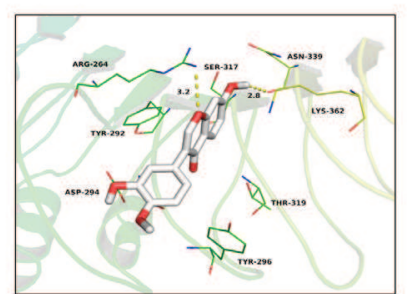

B
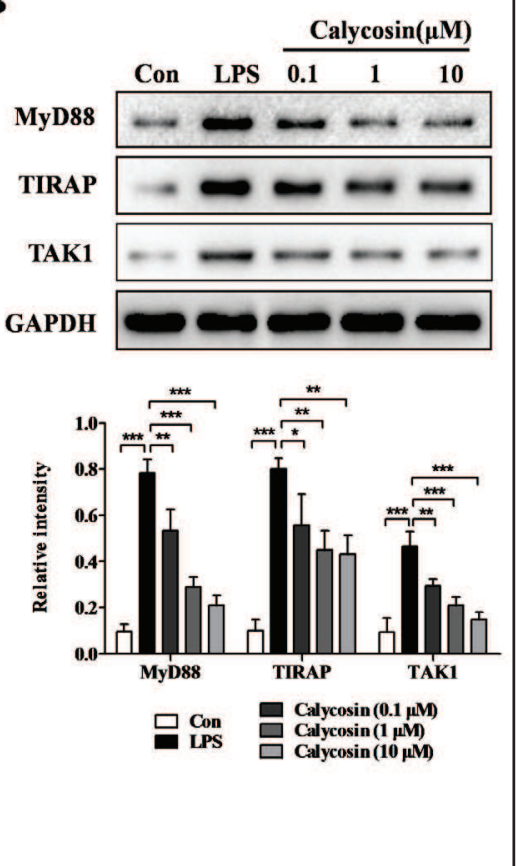
not significant. $P$ -values were analyzed by one-way ANOVA. All data are representative of two to three independent experiments with $n=3$ per group and are means \pm SD.

pathway, regulated the epithelial barrier function and induced the release of TSLP and IL-33. On this basis, calycosin inhibited LPS-induced phosphorylation of NF- $\mathrm{kB}$ dose-dependently 


\section{Cellular Physiology Cell Physiol Biochem 2017;44:1106-1119 \begin{tabular}{ll|l} 
DOI: 10.1159/000485416 & $\begin{array}{l}\text { @ } 2017 \text { The Author(s). Published by S. Karger AG, Basel } \\
\text { www.karger.com/cpb }\end{array}$ \\
and Biochemistry Published online: November 27, 2017 &
\end{tabular} \\ Tao et al.: Calycosin Suppresses Allergic Inflammation}

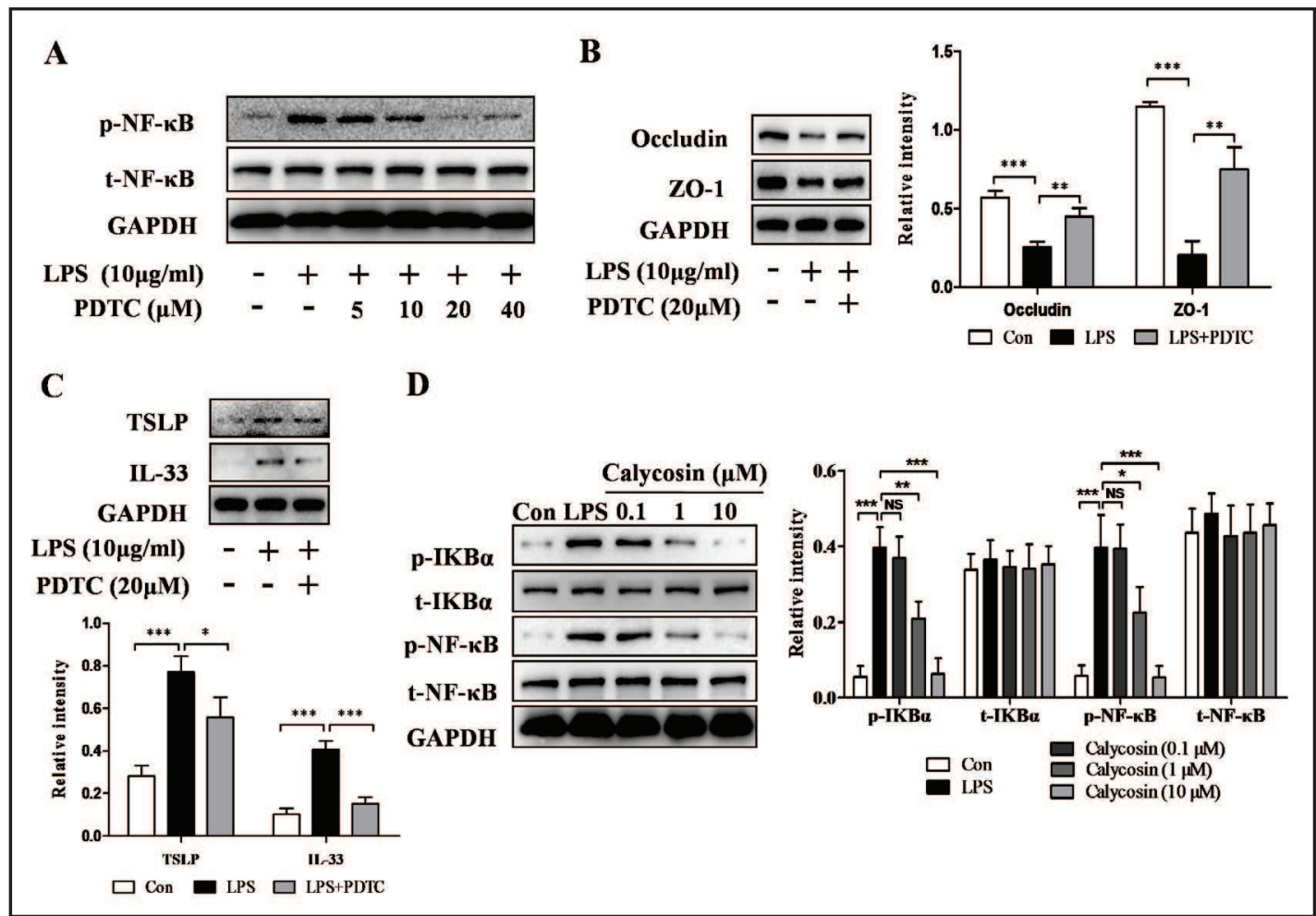

Fig. 7. Calycosin ameliorate LPS-induced expression of TJs and initiative key factors via inhibit NF- $\kappa B$ activation in HaCaT cells. (A) Protein expression of $\mathrm{p}-\mathrm{I} \kappa \mathrm{B}$ and $\mathrm{p}-\mathrm{NF}-\kappa \mathrm{B}$ were measured by Western blot assays. (B) Effect of different concentrations of PDTC on p-NF- $\kappa B$ and NF- $\kappa B$ P65 protein expression by Western blot assays in HaCaT cells. (C) NF- $\kappa B$ inhibitor reduces LPS-induced expression of TJs by Western blot assays in HaCaT cells. (D) NF- $\kappa \mathrm{B}$ inhibitor reduces LPS-induced expression of initiative key factors by Western blot assays in HaCaT cells. ${ }^{*} \mathrm{P}<0.05,{ }^{* *} \mathrm{P}<0.01,{ }^{* * *} \mathrm{P}<0.001$. NS, not significant. $\mathrm{P}$-values were analyzed by one-way ANOVA. All data are representative of two to three independent experiments with $n=3$ per group and are means \pm SD.

and that of IKB $\alpha$ significantly (Fig. 7D). Thus, calycosin inhibited epithelial TJs compromise, and decreased the release of TSLP/IL-33 by blocking TLR4-mediated NF- $\kappa B$ signaling.

\section{Discussion}

Epithelial integrity is compromised during the pathological process of AD and increasing barrier disruption may contribute to facilitate allergens to gain access to immune cells. The intact function of epithelial barrier is mainly determined by TJs, which function as a physical barrier between the external milieu and the internal milieu. It is well-documented that occludin and Z0-1 play important roles in regulating epithelial barrier disruption [6-8]. The mRNA transcriptions and protein expressions of TJ-associated proteins (occluding and ZO-1) significantly reduce following epithelial barrier injury [35]. In an experimental AD model of dogs, TJs (mostly ZO-1 and occludin) are defective [14]. In this study, TEM and Western blot showed that TJs were dysregulated in the initial stage AD model of mice. However, calycosin protected TJs by significantly inhibiting the disruption of occludin and ZO-1.

The epithelial cell barrier disruption is enhanced following stimulation by a variety of inflammatory mediators including LPS [36], an endotoxin in the outer membrane of gram-negative bacteria that can stimulates mononuclear cells and neutrophils to secrete immunoregulatory and pro-allergic cytokines [37]. LPS herein aggravated the epithelium connection damage in $\mathrm{HaCaT}$ cells, being in agreement with a previous literature in Caco- 


\section{Cellular Physiology Cell Physiol Biochem 2017;44:1106-1119 \begin{tabular}{ll|l} 
and Biochemistry & $\begin{array}{l}\text { DOI: 10.1159/000485416 } \\
\text { Published online: November 27, } 2017\end{array}$ & $\begin{array}{l}\text { C } 2017 \text { The Author(s). Published by S. Karger AG, Basel } \\
\text { www.karger.com/cpb }\end{array}$ \\
\hline
\end{tabular} Tao et al.: Calycosin Suppresses Allergic Inflammation}

Fig. 8. Schematic of the proposed mechanism of calycosin on initiative key cytokines release and epithelial barrier disruption in atopic dermatitis. LPS bind the TLR4 results in activating of downstream adaptor molecule of TLR4, such as MyD88, TIRAP and TAK1. TLR4 signaling mediate the activation of NF- $\mathrm{KB}$ induce the TJs (occludin and ZO-1) disruption, and then promote the release of TSLP/IL-33 to form a pro-allergic milieu which may aggravate the process of allergic diseases. Calycosin inhibit the release of TSLP/IL-33 induced by epithelial barrier dysfunction via TLR4 signaling mediate the activation of NF- $\mathrm{\kappa B}$ pathway in vivo and in vitro.

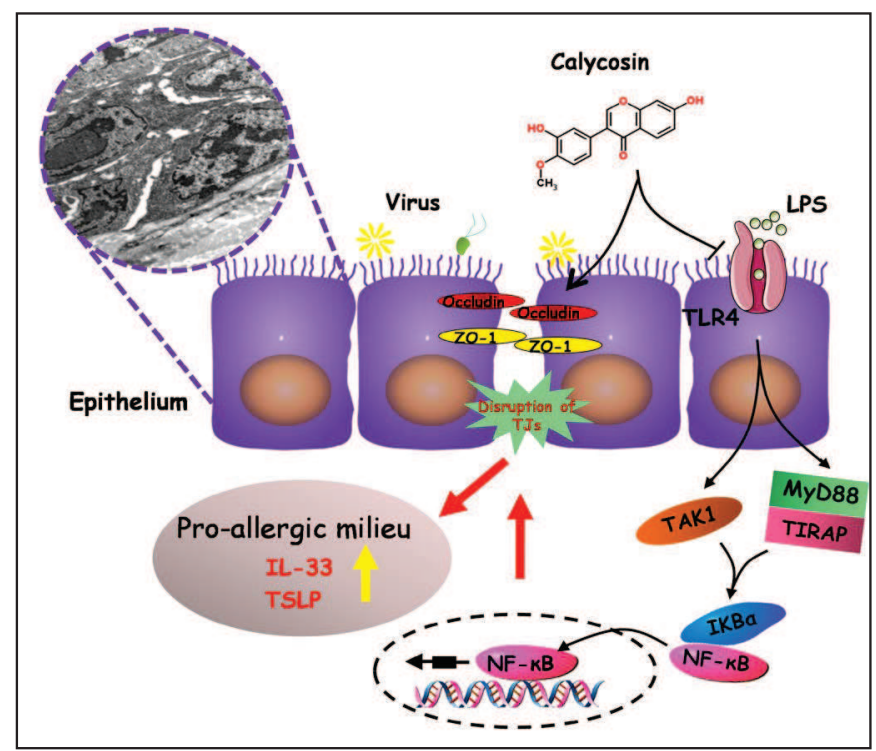

2 cells [38]. Like the results in vivo, calycosin suppressed LPS-induced dysregulation of occludin and ZO-1 in HaCaT cells. Accordingly, calycosin protected the epithelial barrier function both in vivo and in vitro.

The epithelium responds to various environmental factors by releasing key cytokines (TSLP and IL-33) that activate dendritic cells to promote adaptive Th2 cell immunity, and trigger the innate type 2 cell responses by activating of ILC2s, basophils, eosinophils, and mast cells $[39,40]$. In this study, calycosin suppressed the protein and mRNA expressions of TSLP and IL-33 in the initial stage AD model. Moreover, calycosin exerted significant inhibitory effects on the secretions and expressions of these initiative key factors in HaCaT cells.

It was reported that barrier disruption induced the TSLP expression in keratinocytes (KCs), and then promoted Th2 polarization [41]. The epithelial barrier dysfunction and the increase of epithelial paracellular permeability to noxious luminal substances have been closely associated with increases in pro-allergic cytokines upon AD [42]. However, there remains controversy effects of TSLP/IL-33 on the epithelial barrier function. For instance, TSLP is highly expressed in allergic rhinitis and induces the expressions of TJ molecules and the barrier function in human epithelial cells [43]. Meanwhile, the increased expression of mucosal IL-33 in human ulcerative colitis and murine colitis may be a homeostatic response to repressed inflammation by affecting the epithelial barrier function [44]. Thus, TSLP/IL33 release may be associated with epithelium barrier dysregulation, but the relationship between these cytokines and TJs expressions or whether calycosin affects TSLP/IL-33 by increasing TJs expressions still needs in-depth studies.

TLR4 dysregulation is involved in the functions of the intestinal epithelial barrier [45], brain-blood barrier [34], skin epithelial barrier [46], etc. As mentioned above, the mRNA and protein levels of TLR4 were down-regulated by calycosin in vitro and in vivo. Moreover, calycosin significantly suppressed the expressions of MyD88 and TAK1, which were key TLR4 adaptor proteins linking the receptors to downstream kinases.

LPS, a ligand of TLR4, binds TLR4 to activate NF- $\kappa B$, then releasing pro-inflammatory cytokines $[47,48]$ and which may involve the epithelium barrier function as a potential contributor to allergic disease. In our previous study, calycosin down-regulated TSLP expression by blocking the nuclear translocation of NF- $\mathrm{kB}$ in 16HBE cells [3]. We therefore speculated that NF- $\kappa B$ might contribute to TJs disruption and TSLP/IL-33 secretion, and calycosin may affect TJs and TSLP/IL-33 via the NF- $\kappa B$ pathway. As expected, the NF- $\kappa B$ inhibitor PDTC enhanced the expressions of TJs and inhibited the release of initiative key factors induced by LPS in HaCaT cells. Calycosin inhibited LPS-induced phosphorylation of 


\section{Cellular Physiology Cell Physiol Biochem 2017;44:1106-1119 \begin{tabular}{ll|l} 
and Biochemistry & $\begin{array}{l}\text { DOI: 10.1159/000485416 } \\
\text { Published online: November 27, } 2017\end{array}$ & $\begin{array}{l}\text { ( ) } 2017 \text { The Author(s). Published by S. Karger AG, Basel } \\
\text { www.karger.com/cpb }\end{array}$ \\
\hline
\end{tabular} \\ Tao et al.: Calycosin Suppresses Allergic Inflammation}

NF- $\kappa B$ and IKB $\alpha$. Hence, calycosin exerted effects on allergic inflammation by inhibiting the disruption of TJs and the secretion of TSLP/IL-33 in epithelial cells following a mechanism, at least partly, involving the TLR4-NF- $\kappa B$ pathway.

In summary, calycosin inhibited the release of TSLP/IL-33 and protected against epithelial barrier disruption by increasing the expressions of occludin and ZO-1, which may be responsible for the mitigation of allergic inflammation. Moreover, it may exert effects by inhibiting the activation of TLR4-mediated NF- $\kappa B$ signaling pathway (Fig. 8). This study is valuable for unraveling the underlying mechanisms of calycosin as a candidate drug for $\mathrm{AD}$ and other allergic inflammatory conditions, and may provide new drug targets for $\mathrm{AD}$ treatment, although further studies are needed to reveal the accurate relationship between TJs disruption and release of initiative key factors.

\section{Acknowledgements}

This work was supported by the National Natural Science Foundation of China (81473395 and 81373549), the Priority Academic Program Development of Jiangsu Higher Education Institutions, Natural Science Foundation of Jiangsu Province (BK20141466), Jiangsu Key Laboratory for Pharmacology and Safety Evaluation of Chinese (JKLPSE201603) and 2014 Program for Graduate Scientific Innovation of Jiangsu Higher Education Institutions (KYLX_0973).

\section{Disclosure Statement}

The authors confirm that there are no conflicts of interest.

\section{References}

1 Kabashima K: New concept of the pathogenesis of atopic dermatitis: interplay among the barrier, allergy, and pruritus as a trinity. J Dermatol Sci 2013;70:3-11.

-2 Ehling S, Roßbach K, Dunston SM, Stark H, Bäumer W: Allergic inflammation is augmented via histamine H4 receptor activation: The role of natural killer cells in vitro and in vivo. J Dermatol Sci 2016.

3 Shen D, Xie X, Zhu Z, Yu X, Liu H, Wang H, Fan H, Wang D, Jiang G, Hong M: Screening active components from Yu-ping-feng-san for regulating initiative key factors in allergic sensitization. PLoS One 2014;9:e107279.

4 Citi S, Sabanay H, Jakes R, Geiger B, Kendrick-Jones J: Cingulin, a new peripheral component of tight junctions. Nature 1988;333:272-276.

5 Coyne CB, Bergelson JM: Virus-induced Abl and Fyn kinase signals permit coxsackievirus entry through epithelial tight junctions. Cell 2006;124:119-131.

6 Elamin E, Jonkers D, Juuti-Uusitalo K, van Ijzendoorn S, Troost F, Duimel H, Broers J, Verheyen F, Dekker J, Masclee A: Effects of ethanol and acetaldehyde on tight junction integrity: in vitro study in a three dimensional intestinal epithelial cell culture model. PLoS One 2012;7:e35008.

7 Hu YJ, Wang YD, Tan FQ Yang WX: Regulation of paracellular permeability: factors and mechanisms. Mol Biol Rep 2013;40:6123-6142.

-8 Van Itallie CM, Fanning AS, Bridges A, Anderson JM: ZO-1 stabilizes the tight junction solute barrier through coupling to the perijunctional cytoskeleton. Mol Biol Cell 2009;20:3930-3940.

-9 Tsukita S, Furuse M, Itoh M: Multifunctional strands in tight junctions. Nat Rev Mol Cell Biol 2001;2:285293.

10 Furuse M, Itoh M, Hirase T, Nagafuchi A, Yonemura S, Tsukita S, Tsukita S: Direct association of occludin with ZO-1 and its possible involvement in the localization of occludin at tight junctions. J Cell Biol 1994;127:1617-1626. 


\section{Cellular Physiology Cell Physiol Biochem 2017;44:1106-1119 \begin{tabular}{l|l|l} 
DOI:10.1159/000485416 & $\begin{array}{l}\text { ○ 2017 The Author(s). Published by S. Karger AG, Basel } \\
\text { www.karger.com/cpb }\end{array}$ \\
\hline
\end{tabular}}

Tao et al.: Calycosin Suppresses Allergic Inflammation

11 Wang W, Dentler WL, Borchardt RT: VEGF increases BMEC monolayer permeability by affecting occludin expression and tight junction assembly. Am J Physiol Heart Circ Physiol 2001;280:H434-440.

-12 Yuki T, Tobiishi M, Kusaka-Kikushima A, Ota Y, Tokura Y: Impaired Tight Junctions in Atopic Dermatitis Skin and in a Skin-Equivalent Model Treated with Interleukin-17. PLoS One 2016;11:e0161759.

-13 De Benedetto A, Rafaels NM, McGirt LY, Ivanov AI, Georas SN, Cheadle C, Berger AE, Zhang K, Vidyasagar S, Yoshida T, Boguniewicz M, Hata T, Schneider LC, Hanifin JM, Gallo RL, Novak N, Weidinger S, Beaty TH, Leung DY, Barnes KC, Beck LA: Tight junction defects in patients with atopic dermatitis. J Allergy Clin Immunol 2011;127:773-786.

14 Kim HJ, Cronin M, Ahrens K, Papastavros V, Santoro D, Marsella R: A comparative study of epidermal tight junction proteins in a dog model of atopic dermatitis. Vet Dermatol 2016;27:40.

15 Barnes PJ: Immunology of asthma and chronic obstructive pulmonary disease. Nat Rev Immunol 2008;8:183-192.

16 Locksley RM: Asthma and allergic inflammation. Cell 2010;140:777-783.

17 Fahy JV, Locksley RM: The airway epithelium as a regulator of Th2 responses in asthma. Am J Respir Crit Care Med 2011;184:390-392.

18 Sano Y, Masuda K, Tamagawa-Mineoka R, Matsunaka H, Murakami Y, Yamashita R, Morita E, Katoh $\mathrm{N}$ : Thymic stromal lymphopoietin expression is increased in the horny layer of patients with atopic dermatitis. Clin Exp Immunol 2013;171:330-337.

19 Liu YJ: Thymic stromal lymphopoietin: master switch for allergic inflammation. J Exp Med 2006;203:269273.

20 Cevikbas F, Steinhoff M: IL-33: a novel danger signal system in atopic dermatitis. J Invest Dermatol 2012;132:1326-1329.

21 Ryu WI, Lee H, Kim JH, Bae HC, Ryu HJ, Son SW: IL-33 induces Egr-1-dependent TSLP expression via the MAPK pathways in human keratinocytes. Exp Dermatol 2015;24:857-863.

-22 Haapakoski R, Karisola P, Fyhrquist N, Savinko T, Lehtimäki S, Wolff H, Lauerma A, Alenius H: Toll-like receptor activation during cutaneous allergen sensitization blocks development of asthma through IFNgamma-dependent mechanisms. J Invest Dermatol 2013;133:964-972.

-23 Li Z, Wang H, Liu L: Interleukin-25 Enhances Allergic Inflammation through p38MAPK and NF- $\kappa$ B Pathways in Mouse Models of Allergic Rhinitis. Iran J Allergy Asthma Immunol 2014;13:412-419.

24 Chow JY, Wong CK, Cheung PF, Lam CW: Intracellular signaling mechanisms regulating the activation of human eosinophils by the novel Th2 cytokine IL-33: implications for allergic inflammation. Cell Mol Immunol 2010;7:26-34.

25 Shin TY, Kim SH: Meoruh wine suppresses mast cell-mediated allergic inflammation. Immunopharmacol Immunotoxicol 2011;33:271-278.

26 Harada K, Isse K, Sato Y, Ozaki S, Nakanuma Y: Endotoxin tolerance in human intrahepatic biliary epithelial cells is induced by upregulation of IRAK-M. Liver Int 2006;26:935-942.

-27 Shimazu T, Villena J, Tohno M, Fujie H, Hosoya S, Shimosato T, Aso H, Suda Y, Kawai Y, Saito T, Makino S, Ikegami S, Itoh H, Kitazawa H: Immunobiotic Lactobacillus jensenii elicits anti-inflammatory activity in porcine intestinal epithelial cells by modulating negative regulators of the Toll-like receptor signaling pathway. Infect Immun 2012;80:276-288.

-28 Lotz M, Gütle D, Walther S, Ménard S, Bogdan C, Hornef MW: Postnatal acquisition of endotoxin tolerance in intestinal epithelial cells. J Exp Med 2006;203:973-984.

-29 Li DQ, Zhang L, Pflugfelder SC, De Paiva CS, Zhang X, Zhao G, Zheng X, Su Z, Qu Y: Short ragweed pollen triggers allergic inflammation through Toll-like receptor 4-dependent thymic stromal lymphopoietin/OX40 ligand/OX40 signaling pathways. J Allergy Clin Immunol 2011;128:1318-1325.

-30 Aguiniga LM, Yaggie RE, Schaeffer AJ, Klumpp DJ: Lipopolysaccharide Domains Modulate Urovirulence. Infect Immun 2016;84:3131-3140.

31 Trott 0, Olson AJ: AutoDock Vina: improving the speed and accuracy of docking with a new scoring function, efficient optimization, and multithreading. J Comput Chem 2010;31:455-461.

-32 Morris GM, Huey R, Lindstrom W, Sanner MF, Belew RK, Goodsell DS, Olson AJ: AutoDock4 and AutoDockTools4: Automated docking with selective receptor flexibility. J Comput Chem 2009;30:27852791. 


\section{Cellular Physiology Cell Physiol Biochem 2017;44:1106-1119 \begin{tabular}{l|l|l} 
DOI:10.1159/000485416 & $\begin{array}{l}\text { ○ } 2017 \text { The Author(s). Published by S. Karger AG, Basel } \\
\text { www.karger.com/cpb }\end{array}$ \\
\hline
\end{tabular}}

Tao et al.: Calycosin Suppresses Allergic Inflammation

-33 Qin LH, Huang W, Mo XA, Chen YL, Wu XH: LPS Induces Occludin Dysregulation in Cerebral Microvascular Endothelial Cells via MAPK Signaling and Augmenting MMP-2 Levels. Oxid Med Cell Longev 2015;2015:120641.

34 Zhang X, Wang T, Gui P, Yao C, Sun W, Wang L, Wang H, Xie W, Yao S, Lin Y, Wu Q: Resolvin D1 reverts lipopolysaccharide-induced TJ proteins disruption and the increase of cellular permeability by regulating I B $\alpha$ signaling in human vascular endothelial cells. Oxid Med Cell Longev 2013;2013:185715.

-35 Severson EA, Kwon M, Hilgarth RS, Parkos CA, Nusrat A: Glycogen Synthase Kinase 3 (GSK-3) influences epithelial barrier function by regulating occludin, claudin-1 and E-cadherin expression. Biochem Biophys Res Commun 2010;397:592-597.

-36 Nold C, Anton L, Brown A, Elovitz M: Inflammation promotes a cytokine response and disrupts the cervical epithelial barrier: a possible mechanism of premature cervical remodeling and preterm birth. Am J Obstet Gynecol 2012;206:208.

-37 Kim TH, Bae JS: Ecklonia cava extracts inhibit lipopolysaccharide induced inflammatory responses in human endothelial cells. Food Chem Toxicol 2010;48:1682-1687.

38 Chen S, Bu D, Ma Y, Zhu J, Sun L, Zuo S, Ma J, Li T, Chen Z, Zheng Y, Wang X, Pan Y, Wang P, Liu Y: GYY4137 ameliorates intestinal barrier injury in a mouse model of endotoxemia. Biochem Pharmacol 2016;118:5967.

-39 Schmitz J, Owyang A, Oldham E, Song Y, Murphy E, McClanahan TK, Zurawski G, Moshrefi M, Qin J, Li X, Gorman DM, Bazan JF, Kastelein RA: IL-33, an interleukin-1-like cytokine that signals via the IL-1 receptorrelated protein ST2 and induces T helper type 2-associated cytokines. Immunity 2005;23:479-490.

40 Allakhverdi Z, Comeau MR, Jessup HK, Yoon BR, Brewer A, Chartier S, Paquette N, Ziegler SF, Sarfati M, Delespesse G: Thymic stromal lymphopoietin is released by human epithelial cells in response to microbes, trauma, or inflammation and potently activates mast cells. J Exp Med 2007;204:253-258.

-41 Moniaga CS, Jeong SK, Egawa G, Nakajima S, Hara-Chikuma M, Jeon JE, Lee SH, Hibino T, Miyachi Y, Kabashima K: Protease activity enhances production of thymic stromal lymphopoietin and basophil accumulation in flaky tail mice. Am J Pathol 2013;182:841-851.

-42 Hammad H, Lambrecht BN: Barrier Epithelial Cells and the Control of Type 2 Immunity. Immunity 2015;43:29-40.

-43 Kamekura R, Kojima T, Takashima A, Koizumi J, Ogasawara N, Go M, Takano K, Murata M, Tanaka S, Ichimiya S, Himi T, Sawada N: Thymic stromal lymphopoietin induces tight junction protein claudin-7 via NF-kappaB in dendritic cells. Histochem Cell Biol 2010;133:339-348.

44 Waddell A, Vallance JE, Moore PD, Hummel AT, Wu D, Shanmukhappa SK, Fei L, Washington MK, Minar P, Coburn LA, Nakae S, Wilson KT, Denson LA, Hogan SP, Rosen MJ: IL-33 Signaling Protects from Murine Oxazolone Colitis by Supporting Intestinal Epithelial Function. Inflamm Bowel Dis 2015;21:2737-2746.

-45 Wang W, Xia T, Yu X: Wooing suppresses inflammatory response and maintains intestinal barrier function via TLR4-MyD88-TAK1-mediated NF- $\kappa B$ pathway in vitro. Inflamm Res 2015;64:423-431.

-46 Panzer R, Blobel C, Fölster-Holst R, Proksch E: TLR2 and TLR4 expression in atopic dermatitis, contact dermatitis and psoriasis. Exp Dermatol 2014;23:364-366.

-47 Yang S, Li R, Qu X, Tang L, Ge G, Fang W, Qiao Z, Ma J, Hou Y, Liu H: Fosinoprilat alleviates lipopolysaccharide (LPS)-induced inflammation by inhibiting TLR4/NF- $\kappa B$ signaling in monocytes. Cell Immunol 2013;284:182-186.

48 Hou Y, Li G, Wang J, Pan Y, Jiao K, Du J, Chen R, Wang B, Li N: Okanin, effective constituent of the flower tea Coreopsis tinctoria, attenuates LPS-induced microglial activation through inhibition of the TLR4/NF- $\mathrm{B}$ signaling pathways. Sci Rep 2017;7:45705. 